\title{
Tumor Necrosis Factor Ligand Superfamily Member 15
}

National Cancer Institute

\section{Source}

National Cancer Institute. Tumor Necrosis Factor Ligand Superfamily Member 15. NCI

Thesaurus. Code C18289.

Tumor necrosis factor lig and superfamily member 15 (251 aa, $\sim 28 \mathrm{kDa}$ ) is encoded by the human TNFSF15 gene. This protein plays a role in both the inhibition of angiogenesis and the induction of apoptosis. 